\title{
Creation of multi-component fruit and vegetable semi-finished products and confectionery on their basis with health properties
}

\author{
Andreii Zahorulko ${ }^{1}$, Aleksey Zagorulko ${ }^{1}$, Kateryna Kasabova ${ }^{1}$, and Irina Gordienko ${ }^{1}$ \\ ${ }^{1}$ Kharkiv State University of Food Technology and Trade, Department of Processes, Devices and Automation of Food Production, \\ 61051 Kharkov, Ukraine
}

\begin{abstract}
A new method of production of multicomponent fruit and vegetable semi-finished products and sugar confectionery products, in particular pastilles, on its basis has been developed. The recipe of semifinished products is chosen taking into account the health properties, which consists of apples, pumpkins, beets, sea buckthorn and chokeberry. For concentration processes during the production of the semi-finished product, advanced apparatus based on a radiating flexible film resistive electric heater (RFFREH) is used. Rational modes of processing of vegetable raw materials are set for the developed apparatus. Studies of structural and mechanical properties of the proposed multicomponent fruit and vegetable pastes and purees are presented. Analysis of these structural and mechanical properties shows the advantage of multicomponent fruit and vegetable paste with apple puree $-30 \%$, pumpkin $-20 \%$, beets $-10 \%$, sea buckthorn $-20 \%$ and chokeberry $-20 \%$. The use of fruit and vegetable pastes in the technology of pastille gives the products a pleasant taste and aroma, due to which it is possible to use the paste as a natural flavor and dye, without the use of synthetic ones. The use of the developed fruit and vegetable paste in technologies of sugar confectionery, namely pastilles is offered. The optimal application of fruit and vegetable paste is $40 \%$ replacement of apple puree, which will provide a significant increase of physiologically functional ingredients in the product.
\end{abstract}

\section{Introduction}

Deterioration of the ecological condition necessitates the provision of the population with functional food. Consumption of which will prevent diseases and aging of the body, by providing physiological action, will also have a beneficial effect on the target functions of the body, strengthening the health of the consumer. Therefore, one of the main tasks of the food industry is the production of semi-finished products of plant origin to increase the activity of the body's defenses and normal human life. After all, it is organic plant raw materials that contain a significant amount of vitamins, minerals and pectin, phytoncides, etc., and its processing allows to get a lot of different semi-finished food products and finished products. [1-3].

Analysis of publications allows us to conclude that a significant part of fruit or fruit and vegetable pastes are made in one or two components [4]. However, such pastes contain few vitamins, minerals and organic acids; color, aroma and taste are quite poor and aesthetically unattractive. The solution to this problem is possible by expanding the range of pasty semi-finished products by creating multi-component compositions of plant raw materials, which would be characterized by a significant natural content of biologically active substances and therapeutic and prophylactic properties [5].
The main stage of paste production is the concentration of the appropriate puree to achieve a mass fraction of dry matter of $25 \ldots 40 \%$ [6]. And it is during concentration, the duration of which in most evaporators can take about 400 minutes, providing significant losses of biologically active substances. Therefore, of great importance for the food industry is the development and implementation of efficient heat and mass transfer apparatus, the use of which will ensure the production of high quality pasty semi-finished products through the use of gentle temperatures and reducing the duration of the process [7].

The analysis of these materials allows to direct researches in the direction of the improvement of the production processes of health food products by reducing the temperature of concentration within $-45 \ldots 65^{\circ} \mathrm{C}$ [8], it will allow to increase qualitative indicators of the received semi-finished products and confectionery on their basis. At the same time, the introduction of pasty semi-finished products into confectionery recipes is promising for the creation of preventive products, which will expand the existing range [9-10]. There is a sufficient raw material base and scientific potential in Ukraine for the development of this area.

Therefore, the task of developing new methods of production of semi-finished products with a high degree

\footnotetext{
* Corresponding author: zagorulkoAN@ @ hduht.edu.ua
} 
of finishing from fruits and vegetables and expanding the range of food products on their basis with high organoleptic characteristics, nutritional and biological value, low cost and high profitability is urgent.

\section{Experimental}

Experimental studies to improve the method of production of pasty semi-finished products with the high degree of finishing from fruit and vegetable raw materials and confectionery products on their basis were conducted on the basis of the Research Center "Latest biotechnologies and equipment for food production with high health properties" Kharkiv State University of Food and Trade (Ukraine).

During the creation of multicomponent fruit and vegetable semi-finished products, the main raw materials were apple (Antonovka variety), pumpkin (Gilea Muscat variety), beetroot (Bordo variety), sea buckthorn (Galerit variety), chokeberry (Chornooka varieties), which have therapeutic and prophylactic properties, also purees and pastes on their basis. An apple with a high content of pectin substances, which provide interaction with other components, was used as the main part of the multicomponent semi-finished product. Thus, pumpkin is extremely rich in vital substances, antioxidants and vitamins. It contains vitamins $\mathrm{C}, \mathrm{B}_{1}, \mathrm{~B}_{2}, \mathrm{E}, \mathrm{PP}$ and carotenoids. Pumpkin is an excellent source of dietary fiber, carbohydrates and beta-carotene (a powerful antioxidant that gives orange color to vegetables and fruits and is converted into vitamin $\mathrm{A}$ in the body). Consumption of foods rich in beta-carotene reduces the risk of some cancers, protects against asthma and other heart diseases, as well as delays the aging process and degeneration of the body. Pumpkin pulp improves the work of the gastrointestinal tract, promotes bile secretion, increases water and salt metabolism.

Beet contains vitamins $\mathrm{B}_{1}, \mathrm{~B}_{2}, \mathrm{~B}_{5}, \mathrm{C}$, pantothenic (vitamin $\mathrm{B}_{3}$ ) and folic acid, carotenoids; organic (oxalic, malic) acids, proteins and amino acids (lysine, valine, arginine, histidine, etc.). Finally, beet contains significant amounts of iron, manganese, potassium, calcium, cobalt. Cobalt is used for the formation of vitamin $\mathrm{B}_{12}$, which is synthesized by the intestinal microflora in humans and animals. In turn, this vitamin and folic acid are involved in the formation of blood cells - erythrocytes. In general, the complex of $\mathrm{B}$ vitamins has a positive effect on hematopoiesis, normalizes metabolic processes.

The pulp of sea buckthorn fruit contains a large amount of organic acids, sugars, $B$ vitamins $\left(B_{1}, B_{2}, B_{6}\right)$, $\mathrm{C}, \mathrm{E}, \mathrm{K}$, iron, manganese, magnesium, boron, sulfur, silicon and more. Used for the prevention and treatment of sclerosis, strengthening blood vessels, normal nervous function. The use of a rotary film apparatus in the concentration process based on the radiating flexible film resistive electric heater (RFFREH) makes it possible to significantly reduce the duration of heat treatment of products and use low-temperature heat treatment, which preserves the nutritional value of natural raw materials.

Chokeberry fruits contain vitamins $\mathrm{C}$ and PP, carotene, sugars, tannins and organic acids. Used in cardiovascular disease, hypertension and prevention of atherosclerosis, radiation and basal diseases.

Beet and chokeberry were also taken as the natural dye.

Blending experiments were done to substantiate the prescription composition of the fruit and vegetable paste. The selection of natural raw materials was carried out taking into account the content of biologically active substances, organoleptic properties and the influence of structural and mechanical parameters of each of the components on the consistency of the product. Apple was used as a structuring agent because it has a high content of pectin; pumpkin and beet - as a source of dietary fiber; beet due to its unique biochemical composition has a healing effect on the human body. The use of nontraditional vegetable raw materials, namely sea buckthorn and chokeberry allows to enrich the paste with biologically active substances and comply with the value of total acidity at the level of 3.3-3.7 $\mathrm{pH}$ [11].

The production of multicomponent fruit and vegetable pastes was carried out according to the proposed method, which differs from the accepted prescription components and modes of technological processing. The recipe ratio of fruit and vegetable components in multicomponent compositions is given in table I.

According to the developed method, the fruits of sea buckthorn and chokeberry are washed, inspected, separately blanched with steam for $2 \ldots 6$ minutes in the multifunctional apparatus. The berries of sea buckthorn and chokeberry are rubbed to separate the skin and stones. Obtained after rubbing skin with pulp residues are boiled for

5-10 minutes, while the ratio of the mass of the skin and bones with the pulp residues to the mass of water is 1:0.51:0.7. The obtained mass is rubbed.

Apple, pumpkin and beet puree is prepared according to the current technology for the production of fruit and vegetable purees.

Then combine the mass of sea buckthorn and chokeberry, rubbed mass of the decoction of the skin and stones of these berries, apple, pumpkin and beet puree and mix. The fruit and vegetable mass, preheated to a temperature of $40-50{ }^{\circ} \mathrm{C}$, is concentrated in a rotary film apparatus (RFA) (Fig. 1) at a temperature of $50-60{ }^{\circ} \mathrm{C}$ to dry solids content of $28-30 \%$ for $1-1.5 \mathrm{~min}$. Under the conditions of final concentration, the pasty semi-finished product is packaged at a temperature of $56-59^{\circ} \mathrm{C}$, sealed, pasteurized and labeled (table 1).

Table 1. Recipe ratio of fruit and vegetable components in multi-component compositions

\begin{tabular}{|c|c|c|c|}
\hline \multirow{2}{*}{$\begin{array}{c}\text { Component } \\
\text { composition }\end{array}$} & \multicolumn{3}{|c|}{ Composition (sample) } \\
\cline { 2 - 4 } & $1 \mathrm{a}$ & $1 \mathrm{~b}$ & $1 \mathrm{c}$ \\
\hline Apple & 40 & 30 & 20 \\
\hline Pumpkin & 25 & 20 & 15 \\
\hline Beet & 5 & 10 & 15 \\
\hline $\begin{array}{c}\text { Sea } \\
\text { buckthorn }\end{array}$ & 15 & 20 & 25 \\
\hline Chokeberry & 15 & 20 & 25 \\
\hline Control, \% & $\mathbf{1 0 0}$ & $\mathbf{1 0 0}$ & $\mathbf{1 0 0}$ \\
\hline
\end{tabular}




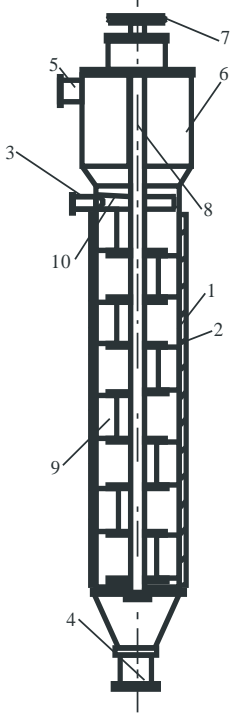

Fig. 1. 1. Advanced rotary film apparatus: 1 - a working chamber;

$2-$ a radiating flexible film resistive electric heater with insulating surface (RFFREH); 3, 4 - pipes for pumping and discharging of raw materials;

5 - a secondary steam discharge pipe; 6 - a separation space; 7 -an electric motor; 8 - a rotor; 9 -a hinged blade; 10 - a distribution ring.

To establish the mechanism and patterns of the processes of formation, deformation and destruction of the structure, changes in the structural and mechanical properties of puree-like compositions according to the recipe ratio were studied. Apple raw material was used as a control sample. The results of research of samples of fruit and vegetable raw materials for pasty semi-finished product are shown in Fig. 2.

As can be seen from Fig. 2 the shear stress for all types of fruit and vegetables differs from zero and is for apple puree $\mathrm{q}_{0}=42 \mathrm{~Pa}$, pumpkin -12 , beet -30 , sea buckthorn -3.5 , chokeberry $-15 \mathrm{~Pa}$. All samples have a shear stress and do not begin to flow immediately after the increase in voltage, ie they belong to imperfectly plastic solids. The increase in the shear stress for all fruit and vegetable raw materials is primarily due to the higher content of dry solids and pectin

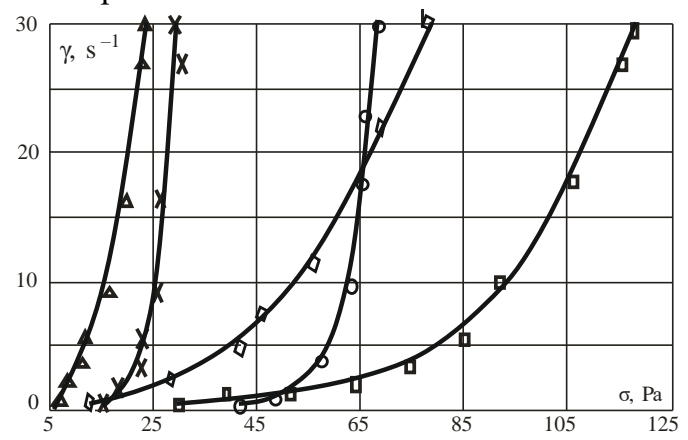

Fig. 2. Shear characteristics of fruit and vegetable raw materials:

${ }$ - apple, $\diamond$ - pumpkin, $\square$ beet, $\times$ chokeberry, $\Delta$ sea buckthorn.

The results of the maximum value of the effective viscosity of the obtained blended paste $\eta_{\mathrm{ef}}(\mathrm{Pa} \cdot \mathrm{s})$ were also obtained for the samples: $1 \mathrm{a}-154 ; 1 \mathrm{~b}-148 ; 1 \mathrm{c}-$
141 and control -127 , respectively (Fig. 3). Thus, the proposed prescription ratios of fruit and vegetable components in multicomponent compositions lead to an increase in the effective viscosity of 10-18\% compared to the control (apple paste), which has a positive effect on strengthening the structure of the pasty semi-finished product.

Analysis of structural and mechanical properties and organoleptic evaluation shows the advantage of multicomponent fruit and vegetable paste with the introduction to the $30 \%$ apple puree pumpkin $-20 \%$, beet $-10 \%$, sea buckthorn $-20 \%$ and chokeberry $-20 \%$ (sample 1b) to the total weight of raw materials. The introduction of pumpkin and beets in large quantities gives an unpleasant specific taste, and in a small amount of sea buckthorn and chokeberry reduces the nutritional value of the product.

Further use of the developed multicomponent fruit and vegetable paste in the technologies of sugar confectionery, namely pastilles. It was previously established that it is optimal to apply a multicomponent paste in the amount of $40 \%$ with the replacement of apple puree, thereby providing a significant increase in physiologically functional ingredients in the obtained products. Taking into account the results of research on the example of the recipe of the pastille "Vitaminka" on the basis of the obtained multicomponent vegetable paste (Table II). An increased number of physiologically functional ingredients in the experimental product, compared with the traditional pastille "Vanilla", is found (Table III)

As can be seen from the above data, the introduction of fruit and vegetable paste can significantly increase the content of confectionery: dietary fiber, organic acids, vitamins (groups B, PP, C, E), phenolic compounds and minerals (magnesium, potassium, phosphorus, iron, calcium).

In addition, in terms of the formulation of blended fruit and vegetable paste, the products get a taste and aroma, confirming the relevance of the use of organic pastes as natural flavors and dyes without the use of their synthetic substitutes.

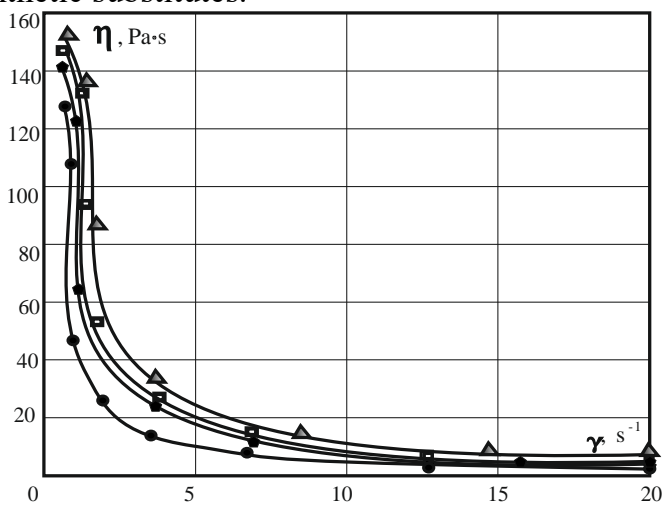

Fig. 3. Shear characteristics of fruit and vegetable raw materials

Complete rheological curve of multicomponent fruit and vegetable pastes: apple control, sample 1b, sample 1a, sample 1c 
Table 2. Recipes Of Pastille "Vitamin" With The Addition Of Fruit And Vegetable Paste

\begin{tabular}{|c|c|c|c|}
\hline & \multirow{2}{*}{$\begin{array}{c}\text { Mass } \\
\text { Name of raw } \\
\text { materials and semi- } \\
\text { finished products }\end{array}$} & $\begin{array}{c}\text { Pastille «Vitaminka» } \\
\text { of dry } \\
\text { solids, } \%\end{array}$ & $\begin{array}{c}\text { Per 1 ton of finished } \\
\text { products }\end{array}$ \\
\cline { 3 - 4 } & $\begin{array}{c}\text { in natural } \\
\text { mass }\end{array}$ & $\begin{array}{c}\text { in dry } \\
\text { solids }\end{array}$ \\
\hline White sugar & 99,85 & 686,0 & 685,0 \\
\hline Powdered sugar & 99,85 & 4,5 & 44,9 \\
\hline Syrup & 78,0 & 107 & 83,5 \\
\hline Apple puree & 10,0 & 366,0 & 36,6 \\
\hline Egg white & 12,0 & 23,3 & 2,8 \\
\hline Agar & 85,0 & 6,0 & 5,1 \\
\hline Lactic acid & 40,0 & 4,2 & 1,7 \\
\hline $\begin{array}{c}\text { Multicomponent } \\
\text { paste }\end{array}$ & 33,0 & 184,8 & 54,9 \\
\hline Together & - & 148,31 & 92,03 \\
\hline Output & $\mathbf{8 5 , 0}$ & $\mathbf{1 0 0 0 , 0}$ & $\mathbf{8 5 0 , 0}$ \\
\hline
\end{tabular}

Table 3. Nutritional Value Of Pastille With The Addition Of Fruit and vegetable Paste

\begin{tabular}{|c|c|c|c|}
\hline Indicator & $\begin{array}{l}\text { Consumpti } \\
\text { on norm }\end{array}$ & $\begin{array}{c}\text { Pastille } \\
\text { "Vanilla"(contr } \\
\text { ol) }\end{array}$ & $\begin{array}{c}\text { Pastille } \\
\text { "Vitamink } \\
\text { a" }\end{array}$ \\
\hline $\begin{array}{c}\text { Caloric } \\
\text { content, kcal }\end{array}$ & & 324,0 & 210,0 \\
\hline $\begin{array}{c}\text { Proteins, g/ } \\
\text { kg }\end{array}$ & $1,5-2,5$ & 0,5 & 0,55 \\
\hline Fat, $\mathrm{g}$ & $45-65$ & 0,5 & 0,5 \\
\hline $\begin{array}{c}\text { Carbohydrat } \\
\text { es, g }\end{array}$ & $150-260$ & 80,0 & 54,5 \\
\hline $\begin{array}{l}\text { Dietary } \\
\text { fiber, } \mathrm{g}\end{array}$ & $25-35$ & 0,8 & 1,8 \\
\hline \multicolumn{4}{|c|}{ Vitamins } \\
\hline $\begin{array}{c}\text { B vitamins, } \\
\text { mg }\end{array}$ & $1,0-2,6$ & 0,01 & 0,03 \\
\hline $\begin{array}{l}\text { Vitamins PP, } \\
\text { mg }\end{array}$ & 20,0 & 0,02 & - \\
\hline $\begin{array}{l}\text { Vitamin } \mathrm{C} \\
\mathrm{mg}\end{array}$ & $75,0-150,0$ & - & 3,0 \\
\hline $\begin{array}{c}\text { Vitamin E, } \\
\text { mg }\end{array}$ & 10,0 & - & 0,98 \\
\hline \multicolumn{4}{|c|}{ Minerals } \\
\hline Sodium, mg & 1300 & 16,0 & 18,5 \\
\hline $\begin{array}{l}\text { Potassium, } \\
\text { mg }\end{array}$ & 2500 & 55,0 & 127,4 \\
\hline Calcium, mg & 1000 & 21,0 & 18,0 \\
\hline $\begin{array}{l}\text { Magnesium, } \\
\text { mg }\end{array}$ & 400 & 7,0 & 11,5 \\
\hline $\begin{array}{c}\text { Phosphorus, } \\
\text { mg }\end{array}$ & 800 & 11,0 & 15,3 \\
\hline Iron, mg & $10,0-20,0$ & 1,6 & 1,6 \\
\hline
\end{tabular}

\section{Conclusion}

A method for the production of a multicomponent fruit and vegetable semi-finished product of a high degree of finishing has been developed and the influence of the mass fraction of each component on the change of structural and mechanical properties of the proposed prescription ratios of pastes has been established. Analysis of these structural and mechanical properties and organoleptic evaluation shows the advantage of multicomponent fruit and vegetable paste with a content of puree with $30 \%$ apples, pumpkin $-20 \%$, beets $-10 \%$, sea buckthorn $-20 \%$ and chokeberry -20

The maximum value of the effective viscosity of the obtained blended pastes ( $\eta$ ef) for the samples: 1a -154 $\mathrm{Pa} \cdot \mathrm{s} ; 1 \mathrm{~b}-148 \mathrm{~Pa} \cdot \mathrm{s} ; 1 \mathrm{c}-141 \mathrm{~Pa} \cdot \mathrm{s}$ and control $-127 \mathrm{~Pa} \cdot \mathrm{s}$, respectively, was determined. Thus, the introduction of other components from 60 to $80 \%$ to apple paste in accordance with the prescription ratio leads to an increase in the effective viscosity of $10 \ldots 18 \%$, which has a positive effect on strengthening the obtained structure of the pasty semi-finished product.

The recipe of the pastille "Vitaminka" with the addition of multi-component fruit and vegetable paste (apple, pumpkin, beet, sea buckthorn and chokeberry) was developed. The introduction of vegetable paste can significantly increase the content of dietary fiber, organic acids, vitamins, phenolic compounds and minerals. Also, with the addition of fruit and vegetable pastes, the samples get taste and aroma, due to which it is possible to use the paste as the natural flavor and dye. Also developed fruit paste can be used as a vitamin supplement in therapeutic and prophylactic nutrition, filler and thickener in various sectors of the food industry, such as confectionery and dairy, as well as for cooking and beverages in catering and at home.

Further research is planned to be directed towards determining the optimal modes of preliminary heat treatment of plant raw materials in order to improve the quality of the obtained semi-finished products and reduce wasteUse a two-column format, and set the spacing between the columns at $8 \mathrm{~mm}$. Do not add any page numbers.

\section{References}

1. A. O. Haiazova, L. S. Prokhasko, M. A. Popova, S. V.Lukynykh, B. K. Asenova, Molodoi uchenyi, 19, 189-191, (2014)

2. N. V. Mykriukova Molodoi uchenyi, 12,. 90-92, (2012)

3. T. Bucher, K. van der Horst, M.Siegrist Appetite, 60, 74-80, (2013)

4. Y. Yorozu, M. Hirano, K. Oka, and Y. Tagawa, IEEE Transl. J. Magn. Japan, 2, 740-741, (1987)

5. L. Huang, L. Ba, X. Zhang, Sh. Gong, Food Quality and Preference, 73, 266-275, (2019)

6. O. Cherevko, V.Mykhaylov, O. Zagorulko, A. Zahorulko, Eastern-European Journal of Enterprise Technologies. 2, 11-17 (2018).

7. L. Kiptelaya, A. Zagorulko, A. Zagorulko, EasternEuropean Journal of Enterprise Technologies, 2,. 48 (2015).

8. A. Zahorulko, A. Zagorulko, N. Fedak, S. Sabadash, D. Kazakov, V. Kolodnenko. Eastern-European Journal of Enterprise Technologies, 6, 6-13 (2019)

9. A.O. Bashta, B.B. Kovalciuk, Harciova promislovisti,. 16, 37-41, (2014) 
10. N.F. Tuz, M.V. Artamonova, Engineering of processing and food production, 1, pp. 32-37, (2016)
11. G.O. Magomedov, A.A. Juravliov, I.V. Plotnikova, T.A. Sheviakova, Vestnik VGUIT, 1, 126-127 (2015) 